Research Article

\title{
The Effects of Biopesticide and Fusarium oxysporum f.sp. vanillae on the Nutrient Content of Binucleate Rhizoctonia-Induced Vanilla Plant
}

\author{
Haryuni Haryuni (D), ${ }^{1}$ Andre Fahriz Perdana Harahap ${ }^{(D)}, 2$ Supartini $\left(\mathbb{D},{ }^{3}\right.$ \\ Achmadi Priyatmojo $\left(\mathbb{D},{ }^{4}\right.$ and Misri Gozan $\mathbb{( D )}^{2}$ \\ ${ }^{1}$ Department of Agronomy, Faculty of Agriculture, Universitas Tunas Pembangunan, Surakarta, Central of Java, Indonesia \\ ${ }^{2}$ Biorefinery Laboratory, Department of Chemical Engineering, Faculty of Engineering, Universitas Indonesia, Kampus UI Depok, \\ Depok 16424, Indonesia \\ ${ }^{3}$ Department of Accounting, Faculty of Economy and Bisnis Universitas Tunas Pembangunan, Surakarta, \\ Central of Java, Indonesia \\ ${ }^{4}$ Department of Phytopathology, Faculty of Agriculture, Universitas Gadjahmada, Yogyakarta, Indonesia
}

Correspondence should be addressed to Misri Gozan; mrgozan@gmail.com

Received 22 October 2019; Revised 3 March 2020; Accepted 20 March 2020; Published 28 April 2020

Academic Editor: Allen Barker

Copyright (c) 2020 Haryuni Haryuni et al. This is an open access article distributed under the Creative Commons Attribution License, which permits unrestricted use, distribution, and reproduction in any medium, provided the original work is properly cited.

\begin{abstract}
Binucleate Rhizoctonia (BNR) fungi are essential for the germination of vanilla seeds. Chemical control of the soil-borne pathogen might adversely affect BNR. The purpose of this study is to determine the effect of Nicotiana tabacum extract biopesticides and Fusarium oxysporum f.sp. vanillae (Fusarium) on vanilla plant nutrient content induced by BNR. Materials and Methods. The research design was completely randomized design with two factors and three replications. The first factor was biopesticide (dosage of $0,10,20$, and $30 \mathrm{ml} /$ seedling), and the second factor was the application of Fusarium. Results. The increase in the nitrogen, phosphorus, and potassium content of vanilla was affected by biopesticides and Fusarium inoculation. Fusarium inoculation has no significant effect on nitrogen and phosphorus levels but significantly affects potassium levels. The biopesticide dosage is significant for nitrogen, phosphorus, and potassium. The interaction of biopesticides with Fusarium inoculation did not significantly affect the parameters of nitrogen and phosphorus content, but significantly affected potassium content. Conclusion. The application of biopesticides and Fusarium inoculation after induction of BNR can increase nitrogen, phosphorus, and potassium content of vanilla plants.
\end{abstract}

\section{Introduction}

In 1819, vanilla came to Indonesia, brought by Marchal from the Botanical Garden of Antwerpen. The production of vanilla began in Central Java and East Java. Then, in the 1960s, it was expanded to Nangro Aceh Darussalam, South Sumatra, Lampung, and Bali. In 1990, the production of vanilla was grown in the east of Indonesia, especially in North Sulawesi, North Maluku, and East Nusa Tenggara [1].

Rhizoctonia is a disease-causing prolific fungus that can make a sclerotium-resistant structure in plant residues. The nucleus inside the cell distinguishes the degree of pathogenicity based on anastomosis (fusion). The group is divided into 14 anastomosis groups, and the group is divided into 3 based on its role (saprophytic, PGPF, and mycorrhizal). Based on the number of nucleus per hyphae, Rhizoctonia is divided into three main groups, namely, uninucleate, binucleate, and multinucleate [2]. Binucleate Rhizoctonia (BNR) acts as mycorrhizae which can increase the resistance of plants from drought and the growth of the plant [3]. On the other hand, this fungus can obstruct the development of Fusarium oxysporum f.sp. vanillae (Fusarium) in vitro [4]. 
Synthetic fungicides are the most popular disease control measure used worldwide by the farmers on various crops [5]. This practice has the potential to kill not only the Rhizoctonia pathogens of crop plants but also the BNR. Biopesticides are used an alternative to synthetic pesticides for safe pest control. The use of plant-based pesticides provides a double advantage, i.e., producing safe products to humans as well as no pollution to the environment [6]. Previous studies on Nicotiana tabacum extracts produced by using solvent extraction as well as pyrolysis methods have shown a significant effect of those extracts on various fungus and insects [7-12]. The extract reduces the protein content of robusta skin, resulting in reduced attack by insects $[11,12]$.

Fusarium is a pathogen present in the soil, and it can infect roots and causes vanilla stem rot disease. It can live as a saprophyte in the soil for 2-4 years. This transmission occurs very quickly through groundwater splashing, water flow, insect attack, contaminated soil, and cuttings of sick plants [13]. Previous work has shown that the treatment dosage of phosphorus and cow urine had a significant effect on chlorophyll and proline content of the vanilla seed [14]. Death of vanilla plants due to the attack of Fusarium oxysporum f.sp. vanillae can reach 50-100\% [15]. Hence, it needs an appropriate control method at the time of breeding and biological control while planting with biopesticides.

Nitrogen is a component of chlorophyll and, therefore, essential for photosynthesis, and also it is the basic element of plant proteins. Plants obtain nitrogen by absorbing either nitrate or ammonium ions through the roots, and it encourages the uptake and utilization of other nutrients, including potassium and phosphorus, and controls the overall growth of plant [16]. Phosphorus plays a major role in the growth of new tissue and in the synthesis of ATP and is responsible for the regulation of protein synthesis [17]. Potassium functions in enzyme activation, stomatal activity (water use), photosynthesis, transport of sugars, water and nutrient transport, protein synthesis, starch synthesis, and crop quality. The effects of $\mathrm{K}$ deficiency can cause reduced yield potential and quality long before visible symptoms appear [18]. In fertilization management strategies, potassium is widely considered to have a role in the mechanism of signaling cascades activation. This mechanism includes triggering reactive oxygen species, phytohormones (ethylene, auxin, and jasmonic acid), calcium ions, and phosphatidic acid [19].

This study aims to determine the effect of Nicotiana tabacum extract as biopesticide and the Fusarium oxysporum f.sp. vanillae (Fusarium) on vanilla plant nutrient content induced by BNR. The BNR induction will decompose the Fusarium, which then improves the availability of nutrients for vanilla growth. This research will also help to understand the mutual interaction between biopesticides and Fusarium to increase the productivity and health of the vanilla plant.

\section{Materials and Methods}

The research was conducted in the greenhouse with a temperature of around $30^{\circ} \mathrm{C}$ from February until July 2017 at the Department of Agronomy, Faculty of Agriculture, Tunas Pembangunan University, Surakarta, Central Java, Indonesia. The vanilla plant was protected by $80 \%$ paranet. The humidity of the room was $60-70 \%$. The greenhouse relies only on natural sunlight, which in our place is stable from 6 am to $6 \mathrm{pm}$ (around $12 \mathrm{hr}$ ).

2.1. Biopesticide Preparation. The biopesticide was prepared by the EHRE extraction method form Nicotiana tabacum var. Virginia origin leaves [7]. This method was carried out at a low temperature and moderate extraction time (ethanol boiling point, $1 \mathrm{~atm}, 6$ hours, $150 \mathrm{rpm}$ ) to obtain optimum biopesticide yield.

2.2. BNR Preparation and Inoculation. BNR was isolated from vanilla roots. Then, the isolates were incubated on a PDA medium. BNR testing was carried out by Koch's postulate. The growing fungus was then transferred and incubated into a sterilized corn medium for three days at $30^{\circ} \mathrm{C}$. After that, $10 \mathrm{~g}$ of BNR from the maize medium was transferred to the plant's root.

2.3. Soil and Sand Preparation. White sand was collected from Klayar Beach, southern part of Pacitan, East Java. Cleaning of sand was carried out by using clean water prior to sterilization. Alfisol soil was collected from Jambu district, Semarang city, Central Java. Soil was cleaned from the remaining roots, stems, and stones prior to sterilization. Sterilization was carried by using the autoclave at $120^{\circ} \mathrm{C}$ for 1 hour.

2.4. Fusarium Preparation and Inoculation. Fusarium was isolated from vanilla stems that had disease symptoms. Then the isolates were incubated on a PDA medium. Fusarium testing was carried out by Koch's postulate. Then, the Fusarium isolate was reproduced in the PDA media. The incubation time was 7 days at $30^{\circ} \mathrm{C}$. A Petri disk of Fusarium was mixed into $75 \mathrm{~g}$ sterile sand media. Each vanilla plant was then transmitted with $5 \mathrm{~g}$ of this mixture. The transmission was placed around the base of the vanilla stem.

2.5. Efficacy Test. Seedling of 10 vanilla seeds from tissue culture was planted in the polybags containing $600 \mathrm{~g}$ of sterile soil medium along with BNR inoculation. After 5 week of BNR inoculation, the prepared biopesticide was sprayed onto the vanilla plant. The biopesticide spraying was done every two weeks in the morning time (between 7 and 8 am), while Fusarium was applied on the same day at around 4-5 pm. This method was also used in the previous studies [20].

Various dosages of biopesticide, i.e., $0,10,20$, and $30 \mathrm{ml} /$ $\mathrm{L}\left(\mathrm{N}_{0}, \mathrm{~N}_{1}, \mathrm{~N}_{2}\right.$, and $\left.\mathrm{N}_{3}\right)$, were applied. The second factor in this study was the inoculation of Fusarium, i.e., with and without Fusarium inoculation $\left(\mathrm{B}_{0}\right.$ and $\left.\mathrm{B}_{1}\right)$.

The root was cut and inoculated into the PDA medium to grow the BNR. Hyphae were taken from this medium and 
TABLE 1: Single factor of biopesticide dosage and Fusarium inoculation

\begin{tabular}{lccccc}
\hline Treatments & Code & Dosage & Nitrogen content (\%) & Phosphorus content (\%) & Potassium content (\%) \\
\hline \multirow{4}{*}{ Biopesticide } & $\mathrm{N} 0$ & $0 \mathrm{ml} / \mathrm{L}$ & $5.00^{\mathrm{a}}$ & $1.15^{\mathrm{a}}$ & $4.04^{\mathrm{a}}$ \\
& $\mathrm{N} 1$ & $10 \mathrm{ml} / \mathrm{L}$ & $5.23^{\mathrm{b}}$ & $1.34^{\mathrm{b}}$ & $4.44^{\mathrm{c}}$ \\
& $\mathrm{N} 2$ & $20 \mathrm{ml} / \mathrm{L}$ & $5.73^{\mathrm{c}}$ & $1.47^{\mathrm{c}}$ & $4.50^{\mathrm{c}}$ \\
\hline \multirow{2}{*}{ Inoculation of Fusarium } & $\mathrm{N} 3$ & $30 \mathrm{ml} / \mathrm{L}$ & $5.76^{\mathrm{d}}$ & $1.53^{\mathrm{c}}$ & $4.25^{\mathrm{b}}$ \\
& $\mathrm{B} 0$ & Without Fusarium & $5.45^{\mathrm{a}}$ & $1.37^{\mathrm{a}}$ & $4.50^{\mathrm{b}}$ \\
& $\mathrm{B} 1$ & With Fusarium & $5.41^{\mathrm{a}}$ & $1.38^{\mathrm{a}}$ & $4.12^{\mathrm{a}}$ \\
\hline
\end{tabular}

Numbers in the same column followed by the same letter are not significantly different according Duncan's Multiple Range Test (DMRT) at a 5\% level.

TABLE 2: Interaction of biopesticide dosage and Fusarium inoculation.

\begin{tabular}{|c|c|c|c|c|c|c|c|c|c|}
\hline \multirow{2}{*}{ Treatment } & \multicolumn{3}{|c|}{ Nitrogen $(\mathrm{N}) \%$} & \multicolumn{3}{|c|}{ Phosphorus (P) \% } & \multicolumn{3}{|c|}{ Potassium (K) \% } \\
\hline & Without $\mathrm{F}^{*}$ & With $\mathrm{F}^{*}$ & Mean & Without $\mathrm{F}^{*}$ & With $\mathrm{F}^{*}$ & Mean & Without $\mathrm{F}^{*}$ & With $\mathrm{F}^{*}$ & Mean \\
\hline $0 \mathrm{ml} / \mathrm{L}$ & $1.72^{\mathrm{a}}$ & $1.61^{\mathrm{a}}$ & $1.66^{\mathrm{a}}$ & $0.39^{\mathrm{a}}$ & $0.37^{\mathrm{a}}$ & $0.38^{\mathrm{a}}$ & $1.45 \mathrm{~cd}$ & $1.24^{\mathrm{a}}$ & $1.34^{\mathrm{c}}$ \\
\hline $10 \mathrm{ml} / \mathrm{L}$ & $1.74^{\mathrm{a}}$ & $1.75^{\mathrm{a}}$ & $1.74^{\mathrm{a}}$ & $0.45^{\mathrm{a}}$ & $0.44^{\mathrm{a}}$ & $0.45^{\mathrm{a}}$ & $1.47 \mathrm{c}-\mathrm{e}$ & $1.49^{\mathrm{c}-\mathrm{f}}$ & $1.48^{\mathrm{e}-\mathrm{f}}$ \\
\hline $20 \mathrm{ml} / \mathrm{L}$ & $1.93^{\mathrm{a}}$ & $1.89^{\mathrm{a}}$ & $1.91^{\mathrm{a}}$ & $0.48^{\mathrm{a}}$ & $0.50^{\mathrm{a}}$ & $0.49^{\mathrm{a}}$ & $1.57 \mathrm{gh}$ & $1.43^{\mathrm{c}}$ & $1.50^{\mathrm{c}-\mathrm{g}}$ \\
\hline $30 \mathrm{ml} / \mathrm{L}$ & $1.88^{\mathrm{a}}$ & $1.96^{\mathrm{a}}$ & $1.92^{\mathrm{a}}$ & $0.50^{\mathrm{a}}$ & $0.52^{\mathrm{a}}$ & $0.51^{\mathrm{a}}$ & $1.5 \mathrm{c}-\mathrm{g}$ & $1.33^{\mathrm{b}}$ & $1.41^{\mathrm{c}}$ \\
\hline
\end{tabular}

${ }^{*} \mathrm{~F}=$ Fusarium oxysporum f.sp. vanillae; number in the same column followed by the same letter are not significantly different according to Duncan's Multiple Range Test (DMRT) 5\%.

placed onto a glass object with Safranin dye staining. Methylene blue dye staining was used to observe the peloton. Both observations were done by using the binocular microscope MICRON Brand Doctor's Binocular Research Microscope BINO CXL with 50x magnification.

2.6. $N, P$, and $K$ Analysis. Nitrogen of vanilla plant tissues was analyzed using Kjeldahl methods [21]. Phosphorus and potassium of plant tissues were analyzed using the dry ashing or wet ashing $\left(\mathrm{HNO}_{3}-\mathrm{HCLO}_{4}-\mathrm{H}_{2} \mathrm{SO}_{4}\right.$ triacid method or $\mathrm{HNO}_{3}-\mathrm{HCLO}_{4}$ diacid method) [22].

2.7. Statistical Data Analysis. Analysis of variance (ANOVA) was carried out in this study. If there was a difference between treatments, then it was tested further by using Duncan's New Multiple Range Test (DMRT) at a 5\% level. Regression and correlation analyses were carried out to find the relationship between direct and indirect influence [23].

\section{Result}

The effect of a single factor of biopesticide dosage and Fusarium inoculation on $\mathrm{N}, \mathrm{P}$, and $\mathrm{K}$ of vanilla plants is depicted in Table 1.

The results of data analysis (Table 1 ) showed that the dosage of biopesticides influenced the $\mathrm{N}$ and $\mathrm{P}$ content.

The effect of interaction of biopesticide dosage and Fusarium inoculation on $\mathrm{N}, \mathrm{P}$, and $\mathrm{K}$ of vanilla plants is depicted in Table 2.

Numbers in the same columns of $\mathrm{N}$ and $\mathrm{P}$ treatments followed by the same letter indicate the interactions were not significantly different according to Duncan's Multiple Range Test (DMRT) 5\%. Meanwhile, the $\mathrm{K}$ treatment shows different letters, which indicate the interactions were significantly different.
The regression analysis of Fusarium treatment on vanilla plants is depicted in Table 3.

\section{Discussion}

4.1. The Effect of Biopesticide on the Binucleate Rhizoctonia $(B N R)$. Figures 1 and 2 show that the inoculated BNR during vanilla planting has an impact on the resistance, infecting the root part of the intracellular hyphae in the form of a solid winding called a peloton. This phenomenon was also similar to other studies $[3,24]$. The ability of BNR to degrade chitin shows that it can be classified as a biopesticide. The use of microorganisms as biopesticides can provide many benefits because they act as enzyme producers and plant growth-promoting fungi (PGPR) that produce growth regulatory metabolites and provide nutrients to plants $[3,25,26]$.

BNR infects and forms peloton in the vanilla plant tissue. Then, the decomposition of the infected Fusarium lysate cell walls inhibits the conidia germination of Fusarium in vitro. The decomposed Fusarium provides nutrients. Thus, the existence of Fusarium is not as a pathogen but a source of nutrition for BNR.

The biopesticide from Nicotiana tabacum extract used in this study did not disturb the function of endogenous binucleate Rhizoctonia (BNR), which is very essential in the vanilla farming to avoid water stress.

4.2. The Effect of Biopesticide and Fusarium on the Plant Nutrient. Table 1 shows that the biopesticide application has significantly increased the N, P, and K content of the vanilla plant. However, the Fusarium has significantly increased only the K content of the vanilla plant. The increase in the $\mathrm{N}$ content was as result of biopesticide and Fusarium inoculation. The biopesticide has some $\mathrm{N}$-containing compounds or groups such as 3-(1-methyl-2-pyrrolidinyl)-pyridine 
TABle 3: Regression analysis of Fusarium treatment on vanilla plants.

\begin{tabular}{|c|c|c|c|c|c|c|}
\hline & & & Linear $e$ & analysis & & \\
\hline & & t Fusarium & & & Fusarium & \\
\hline $\mathrm{N}$ & $y=0.067 x+1.65$ & $R^{2}=0.6998$ & $r=0.84$ & $y=0.119 x+1.505$ & $R^{2}=0.9797$ & $r=0.99$ \\
\hline $\mathrm{P}$ & $y=0.036 x+0.365$ & $R^{2}=0.9391$ & $r=0.97$ & $y=0.051 x+0.33$ & $R^{2}=0.951$ & $r=0.97$ \\
\hline K & $y=0.025 x+1.435$ & $R^{2}=0.3776$ & $r=0.61$ & $y=0.021 x+1.32$ & $R^{2}=0.0605$ & $r=0.24$ \\
\hline
\end{tabular}

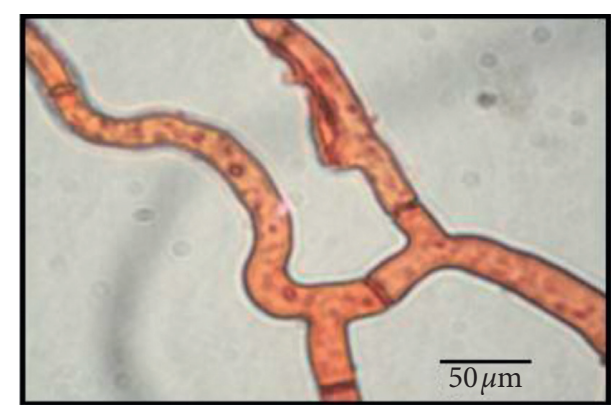

FIGURE 1: Hyphae binucleate Rhizoctonia (BNR) of the vanilla root under the binocular microscope (50x magnification).

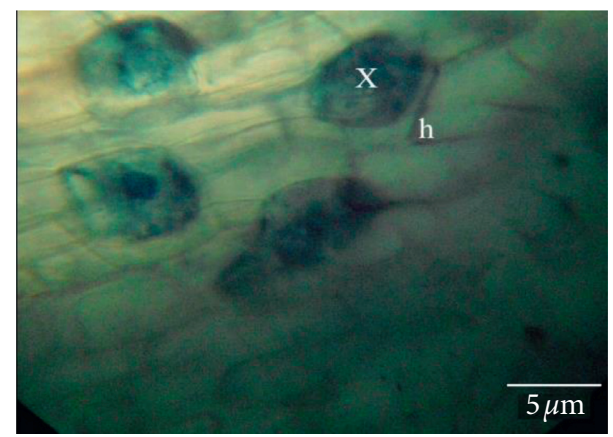

FIGURE 2: Vanilla root tissue inoculated by BNR: (x) peloton and (h) internal hyphae, under binocular microscope $(50 \mathrm{x}$ magnification).

$\left(\mathrm{C}_{10} \mathrm{H}_{14} \mathrm{~N}_{2}\right)$, 3-methyl-pyridine $\left(\mathrm{C}_{6} \mathrm{H}_{7} \mathrm{~N}\right)$, 4-hydroxypyridine $\left(\mathrm{C}_{5} \mathrm{H}_{5} \mathrm{NO}\right)$, and $1 \mathrm{H}$-indole $\left(\mathrm{C}_{8} \mathrm{H}_{7} \mathrm{~N}\right)$ [24].

Table 3 shows the effect of interaction dosage of biopesticides and Fusarium inoculation was not significantly different for Nitrogen and Phosphorus contents. The biopesticide treatment with the presence of Fusarium has a slightly higher correlation coefficient $(r=0.99)$ than that without the presence of Fusarium $(r=0.84)$. Table 1 shows that the biopesticide dose significantly affected the content of Nitrogen, Phosphorus and Potassium. However, the effect of the Fusarium dose alone was not significantly different on the nitrogen and phosphorus content. On the contrary, Table 2 shows that increasing the doses of biopesticides and adding Fusarium inoculation significantly affected the potassium content. Regression analysis (Table 3) also confirmed this as indicated by the correlation coefficient values $r=0.61$ (without Fusarium) and $r=0.24$ (with Fusarium).

This fact reveals that after induction of BNR, the addition of this biopesticide kills the soil-borne pathogens, i.e., Fusarium oxysporum f.sp Vanillae, and can increase vanilla plant nutrition. This means that the biopesticide interacts mutually with BNR to increase the $\mathrm{N}, \mathrm{P}$, and $\mathrm{K}$ content in the vanilla plant. This mutual interaction to increase the nutrient in the vanilla plant is important because all the nutrients are essential for the plant growth and productivity.

Nitrogen is an essential component of proteins, genetic material, chlorophyll, and other key organic molecules. All organisms require nitrogen to live. It ranks fourth behind oxygen, carbon, and hydrogen as the most common chemical element in living tissues [27]. Deficiency in these compounds directly affects feeding power, growth, and reproductive power, inhibits reproduction communication, decreases hatchability of eggs, and inhibits the formation of chitin [28].

Phosphorus elements affect flowering, pollination, and maturation of fruit. The $\mathrm{P}$ content of tissue is affected by its availability in the soil. It is influenced by the state and uptake of soil microorganisms that are transferred to plants through plant roots [29]. $\mathrm{P}$ is the main element used by the plants for growth and energy sources, in the form of organic compounds. $\mathrm{BNR}$ that is induced in vanilla seeds requires phosphorus, which is utilized by BNR fungi in the form of sugar-phosphate, the oxidation of nucleoprotein, and protein phosphorus [15]. Phosphate is an important element of protein formation and cell metabolic processes of organisms [30].

Vanilla which is induced by Rhizoctonia binucleat (BNR) then infected with Fusarium influences the increase of plant phosphorus content [31]. Phosphorus is an essential nutrition for plant growth. A huge amount of phosphate is present in the soil, but around 95\% to 99\% phosphorus is unavailable, so it cannot be used by plants [32]. The most important chemical reaction in nature is photosynthesis. It utilizes light energy in the presence of chlorophyll to combine carbon dioxide and water into simple sugars, with the energy being captured in ATP [33].

According to the statistical data (Table 2), the increase in potassium was strongly related to the interaction between the application of biopesticides and Fusarium. This interaction may dissolve $\mathrm{K}$ into available forms that are easily absorbed and utilized by plants. $\mathrm{K}$ is an essential nutrient and also the most abundant cation in plants. The concentration of $\mathrm{K}^{+}$in the cytoplasm has consistently been found to be between 100 and $200 \mathrm{~mm}$, and apoplast $\mathrm{K}^{+}$concentration is between 10 and 200 or even reaches up to $500 \mathrm{~mm}$. K plays essential roles in enzyme activation, protein synthesis, photosynthesis, osmoregulation, stomatal movement, energy transfer, phloem transport, cation-anion balance, and stress resistance $[34,35]$.

In K-sufficient plants, the synthesis of high-molecularweight compounds (such as proteins, starches, and cellulose) is markedly increased. They thereby depress the concentrations 
of low-molecular-weight compounds, such as soluble sugars, organic acids, amino acids, and amides in the plant tissues. These low-molecular-weight compounds are important for the development of infectious diseases, inferior plants, and plantderived inhibitors (K-sufficient plants) [36]. K also can increase plant resistance to pathogens due to increased phenol concentrations [35].

$\mathrm{K}$ is associated with water, nutrients, and carbohydrates in plant tissues. Potassium is involved in enzyme activation within the plant, which affects protein, starch, and adenosine triphosphate (ATP) production. The production of ATP can regulate the rate of photosynthesis. Potassium also helps to regulate the opening and closing of the stomata, which regulates the exchange of water vapor, oxygen, and carbon dioxide. If $\mathrm{K}$ is deficient or not supplied in adequate amounts, growth is stunted and yield is reduced [29, 37].

\section{Conclusion}

The biopesticide from Nicotiana tabacum extract used in this study did not disturb the function of endogenous binucleate Rhizoctonia (BNR), which is very essential in the vanilla farming to avoid water stress. This study has also revealed that after induction of BNR, the addition of this biopesticide kills the soil-borne pathogens, i.e., Fusarium oxysporum f.sp vanillae, and can increase vanilla plant nutrition. This means that the biopesticide interacts mutually with BNR to increase the $\mathrm{N}, \mathrm{P}$, and $\mathrm{K}$ content, which in turn has very important roles in the health and productivity of the vanilla plant.

\section{Data Availability}

The data used to support the findings of this study are available from the corresponding author upon request.

\section{Conflicts of Interest}

The authors declare that they have no conflicts of interest.

\section{Acknowledgments}

The authors gratefully acknowledge the research grants from the Directorate General of Higher Education, Ministry of Research, Technology, and Higher Education, the Republic of Indonesia (Nr.: 009/K6/KM/SP2H/PENELITIAN/2018), and the research grant from Universitas Indonesia through Hibah Q1Q2 scheme (Nr.: NKB-0310/UN2.R3.1/HKP.05.00/ 2019).

\section{References}

[1] H. N. R. A. Supriadi, D. Pranowo, and M. Hadad, "Vanilla performance in East Nusa Tenggara," Buletin Ristri, vol. 1, no. 2, pp. 94-100, 2008.

[2] A. Priyatmojo, Y. Yotani, K. Hattori, K. Kageyama, and M. Hyakumachi, "Characterization of Rhizoctonia spp. causing root and stem rot of miniature rose," Plant Disease, vol. 85, no. 11, pp. 1200-1205, 2001.

[3] H. Haryuni, Studies on Binucleate Rhizoctonia as a Mycorrhiza and its Role in Increasing Vanilla Seedling Resistance toward Drought Stress (Vanilla Planifolia Andrews) against
Drought Stress. Dissertation, Universitas Gadjah Mada, Yogyakarta, Indonesia, 2012.

[4] Haryuni, T. Supriyadi, and T. S. K. Dewi, "The effectiveness of binucleate Rhizoctonia on the development of stem rot pathogen of vanilla (Fusarium oxysporum f.sp Vanilla) in vitro,” Agrineca, vol. 14, no. 2, pp. 171-179, 2014.

[5] H. R. Kataria and U. Gisi, "Chemical control of Rhizoctonia species," in Rhizoctonia Species: Taxonomy, Molecular Biology, Ecology, Pathology and Disease Control, B. Sneh, S. JabajiHare, S. Neate, and G. Dijst, Eds., Springer, Dordrecht, Netherlands, 1996.

[6] D. Nadia, D Singh, Different plant families as biosource of pesticides," in Advanced In Plant Biopesticides, pp. 1-20, Springer, New Delhi, India, 2014.

[7] A. Fauzantoro, Y. Muharam, and M. Gozan, "Improvement of nicotine yield by ethanolic heat reflux extraction of Nicotiana tabacum var. Virginia origin of ponorogo," International Journal of Applied Engineering Research, vol. 12, no. 23, pp. 13891-13897, 2017.

[8] D. A. A. Putra, A. Pramono, Anisah, A. Fauzantoro, and M. Gozan, "The effect of tobacco leaves pyrolysis extract (Nicotiana tabacum L.var. Virginia ) against the formation of biofilm by Staphylococcusaureus: an in-vitro study," IOP Conference Series: Materials Science and Engineering, vol. 508, Article ID 012147, 2019.

[9] Y. Sentosa, H. N. Andjani, K. Yati, M. Jufri, Haryuni, and M. Gozan, "Determination of $\mathrm{LC}_{50}$ value of Nicotiana tabacum L. extract against Tenebrio molitor and Zophobas morio larvae," in The 4th Biomedical Engineering's Recent Progress in Biomaterials, Drugs Development, Health, and Medical Devices: Proceedings of the International Symposium of Biomedical Engineering (ISBE) 2019, vol. 2193, no. 1, pp. 1-6, Padang, Indonesia, July 2019.

[10] H. N. Andjani, Y. Sentosa, K. Yati, M. Jufri, A. Fauzantoro, and M. Gozan, "Determination of $\mathrm{LC}_{50}$ value of Nicotiana tabacum L. extract against Gryllus bimaculatus imago and Galleria mellonella larvae," in Proceedings of the AIP Conference, vol. 2193, no. 1, Padang, Indonesia, July 2019.

[11] H. Haryuni, T. S. K. Dewi, E. Dewi, S. F. Rahman, and M. Gozan, "The effect of Beauveria bassiana on the effectiveness of Nicotiana tabacum extract as biopesticide against Hypothenemus hampei to robusta coffee," International Journal of Technology, vol. 10, no. 1, pp. 159-166, 2019.

[12] T. S. K. Dewi, H. Supartini, E. Suprapti et al., "Effect of Nicotiana tabacum extract concentration as biopesticide on protein content of robusta coffee beans and skin," in Proceedings of the International Conference on Science and Education and Technology, vol. 247, pp. 565-567, Semarang, Indonesia, August 2018.

[13] G. N. Agrios, Plant Pathology, Elsevier Academic Press, New York, NY, USA, 5th edition, 2005.

[14] E. S. Haryuni, T. S. K. Dewi, T. Supriyadi, A. A. Nugroho, A. Priyatmojo, and M. Gozan, "Phosphorus dosage and cow urine to chlorophyll and proline content on binucleate Rhizoctonia by induced resistance of vanilla," in Proceedings of the International Conference on Science and Education and Technology, vol. 247, pp. 215-218, Semarang, Indonesia, August 2018.

[15] E. Nurcahyani, I. Sumardi, B. Hadisutrisno, and Suharyanto, "Suppression of development of vanilla foot rot disease (Fusarium oxysporum f.sp Vanilla) through in vitro fusaric acid selection," Jurnal HPT Tropika, vol. 12, no. 1, pp. 12-22, 2012.

[16] S. J. Leghari, N. A. Wahacho, G. M. Laghari et al., "Role of nitrogen for plant growth and development: a review," 
Advances in Environmental Biology, vol. 10, no. 9, pp. 209218, 2016.

[17] A. Abdolzadeh, X. Wang, E. J. Veneklaas, and H. Lambers, "Effects of phosphorus supply on growth, phosphate concentration and cluster-root formation in three Lupinus species," Annals of Botany, vol. 105, no. 3, pp. 365-374, 2010.

[18] K. Prajapatil and H. A. Modi, "The importance of potassium in plant growth-a review," Indian Journal of Plant Sciences, vol. 1, no. 2-3, pp. 177-186, 2012.

[19] C. Hafsi, A. Debez, and C. Abdelly, "Potassium deficiency in plants: effects and signaling cascades," Acta Physiologiae Plantarum, vol. 36, no. 5, pp. 1055-1070, 2014.

[20] T. S. K. D. Haryuni and T. Nuryati, The Effect of Rhizoctonia Binucleat (Bnr) and Dose of Phosphor to Growth Vanilla Seedling (Vanilla Planifolia Andrew), pp. 36-45, The 2nd University Research Colloquium, New Delhi, India, 2015.

[21] J. Kjeldahl, "A new method for the estimation of nitrogen in organic compounds," Analytical Chemistry, vol. 22, p. 366, 1883.

[22] J. R. Okalebo, Laboratory Methods of Soil and Plant Analysis: A Working Manual, Department of Soil Science, Moi University, Chepkoilel Campus, Eldoret, Kenya, 2002.

[23] K. A. Gomez and A. A. Gomez, Statistical Procedures for Agricultural Research, Wiley-Interscience Publication, New York, NY, USA, 2nd edition, 1984.

[24] A. Fauzantoro, Peningkatan Kadar Nikotin Dengan Ekstraksi Panas Refluks Etanol Pada Nicotiana Tabacum Var. Virginia Dan Feasibilitas Aplikasinya Untuk Produksi Biopestisida Skala Komersial, Dissertation, Universitas Indonesia, Depok, Indonesia, 2018.

[25] E. J. Pope and D. A. Carter, "Phylogenetic placement and host specificity of mycorrhizal isolates belonging to AG-6 and AG12 in the Rhizoctonia solani species complex," Mycologia, The Mycological Society of America, vol. 93, no. 4, , pp. 712-719, Lawrence, 2001.

[26] R. Saraswati, "Application of soil microorganisms as a component of agriculture technology," Iptek. Tan. Pangan, vol. 3, p. 41, 2008.

[27] H. Haryuni and T. S. K. Dewi, "The effects of dose Rhizoctonia binucleat (BNR) and phosphorus to nitrate reductase activity (NRA) and chlorophyll of vanilla seedling (Vanilla planifolia andrews)," Biosaintifika: Journal of Biology \& Biology Education, vol. 8, no. 2, pp. 141-147, 2016.

[28] M. T. Glio, Membuat Pestisida Nabati Untuk Hidroponik, Akuaponik, Vertikultur, Dan Sayuran Organik, Agromedia Pustaka, Jakarta, Indonesia, 2018.

[29] P. E. Thornton, J.-F. Lamarque, N. A. Rosenbloom, and M. M. Mahowald, "Influence of carbon-nitrogen cycle coupling on land model response to $\mathrm{CO}_{2}$ fertilization and climate variability," Global Biogeochemical Cycles, vol. 21, no. 4, 2007.

[30] C. Qiao, L. Liu, S. Hu, J. E. Compton, T. L. Greaver, and Q. Li, "How inhibiting nitrification affects nitrogen cycle and reduces environmental impacts of anthropogenic nitrogen input," Global Change Biology, vol. 21, no. 3, pp. 1249-1257, 2015.

[31] J. T. Havlin, S. L. Tisdale, W. L. Nelson, and J. D. Beaton, Soil Fertility and Fertilizers: An Introduction to Nutrient Management, Pearson, New Delhi, India, 8th edition, 2016.

[32] A.-L. Barabási and Z. N. Oltvai, "Network biology: understanding the cell's functional organization," Nature Reviews Genetics, vol. 5, no. 2, pp. 101-113, 2004.

[33] Haryuni, T. S. K. Dewi, T. Supriyadi, and Supriyadi, "Research of while Fusarium infected and dosage of rice chaff on the increasing of pathogen stem rot resilience of vanilla (BBV) which induced of Rhizoctonia binucleate (BNR) and the effect on the increasing of organic matters and soil phosphorus," in Proceeding of the Advances in Global Business Research, vol. 13, no. 1, pp. 1975-1983, 2016.

[34] P. Sanjotha, P. Mahantesh, and C. S. Patil, "Isolation and screening of efficiency of phosphate solubilizing microbes," International Journal of Microbiology Research, vol. 3, pp. 56-58, 2011.

[35] J. L. Poulton, D. Bryla, R. T. Koide, and A. G. Stephenson, "Mycorrhizal infection and high soil phosphorus improve vegetative growth and the female and male functions in tomato," New Phytologist, vol. 154, no. 1, pp. 255-264, 2002.

[36] R. E. Engel, "Technical session II. Role of potassium in plant physiology," Chloride Requirements for Wheat Production and Leaf Spot Suppression, Department of Land Resources and Environmental Sciences Montana State University, , pp. 218-232, Bozeman, Montana, U.S.A..

[37] M. Wang, Q. Zheng, Q. Shen, and S. Guo, "The critical role of potassium in plant stress response," International Journal of Molecular Sciences, vol. 14, no. 4, pp. 7370-7390, 2013. 